\title{
The Qur'ān and Woman's Leadership Discourse in Indonesia: Modern Interpretation of QS. 4: 34
}

\author{
Kusmana $^{1}$
}

\begin{abstract}
The interpretation of QS. 4: 34 gains a new popularity in modern era as it has been used and abused as one of the references in discussing gender discourse in Islam. The paper discusses it in relation to woman's leadership in modern Indonesian context. Hard-liners' perceptions such as that of Salafi 's interpretation is excluded in this discussion. It deserves another adequate discussion. The paper also restricts its discussion to the thoughts of Hamka, M. Quraish Shihab, Husein Muhammad, and of Ministry of Religious Affairs' interpretation and treats them as exemplary of what is going on in the field of Qur'anic interpretation in this context. Using a descriptive-analytic method, this study deploys a library review technique in answering its question of the study, "how modern Muslim Indonesian scholars interpret the QS. 4: 34 in the context of democracy of Indonesia? The study concludes that they in deciphering the verse tend to adapt the demand of democracy but with a careful maintenance of the traditional wisdom.
\end{abstract}

\begin{abstract}
Abstrak
Penafsiran QS. 4: 34 meraih popularitas baru di era modern karena telah dimanfaatkan dan disalahgunakan sebagai salah satu rujukan untuk mendiskusikan wacana gender dalam Islam. Makalah ini mendiskusikan ayat ini dalam kaitannya dengan kepemimpinan perempuan dalam kontek Indonesia modern. Persepsi garis keras seperti penafsiran Salafi tidak dibahas di sini karena hal tersebut memerlukan pembahasan lain yang memadai. Makalah ini juga membatasi diskusinya pada pemikiran Hamka, M. Quraish Shihab, Husein Muhammad, dan penafsiran Kementrian Agama, dan memperlakukan mereka sebagai contoh terhadap apa yang terjadi dalam kajian al-Qur'an seputar isu tersebut. Dengan menggunakan metode deskrif-analitik, kajian ini melakukan telaah kepustakaan dalam menjawab pertanyaan penelitiannya, "bagaimana sarjana muslim Indoensia modern menafsirkan QS. 4: 34 dalam konteks demokrasi Indonesia? Kajian ini menyimpulkan
\end{abstract}

${ }^{1}$ Lecturer at Faculty of Ushuluddin, UIN Syarif Hidayatullah Jakarta. Email: kusmana@uinjkt.ac.id 
bahwa mereka dalam memahami ayat ini cenderung untuk mengadaptasi tuntutan demokrasi, tapi dengan pemeliharan hatihati atas kebijaksanaan tradisional.

Keywords: Tafsïr al-Qur'an, Feminism, Gender, Kodrat Perempuan, and Leadership.

\section{Introduction}

About more than two decades ago in 1994, a young scholar who just finished his master at Institute for Islamic Studies, McGill University, Didin Syafruddin made an analysis on the interpretation of QS 4: 34 in Ulumul Qur'an. ${ }^{2}$ He basically mapped different opinions on the status of woman over men in the views of classical interpreters and its relevance and significance in modern context. He argued that the verse was one of the main resources where interpreters derived and deduced to illustrate the superiority of men over women. This superiority is characterized as God's order, breadwinner, protection, woman's nature or kodrat, ubiquity, strength, and smartness. These points were commonly proposed by classical Muslim interpreters. However, the relevance and significance of this stand began to receive criticism in modern time. He mentioned Fazlur Rahman, Amina Wadud, Asghar Ali Engineer, and Fredda Hasan to illustrate recent studies. Unlike classical interpreters, many of Muslim scholars in modern age began to treat the verse as informative and not normative. By saying it so, through their lenses, Syafruddin identified the need to apply new approach or to reinterpret the verse in a more equal and democratic nuance. ${ }^{3}$

Ulumul Qur'an (UQ) issued Ali Asghar Engineer's article, "Perempuan dalam Syari'ah: Perspektif Feminis dalam penafsiran Islam" [Woman in Shari'ah: a Feminist Perspective in Islamic Interpretation] (UQ, No. 3, Vol. V, 1994). This publication triggered further discussion. The following issuance of UQ, no 5 and 6, Vol. V, 1994 woman was presented as its main theme, where Syafruddin's article was included as the first paper of the "Analisis" rubric. This issue was special, celebrating Mother Day and five years of UQ's publication. UQ termed this response which was based on the spirit of feminism as counterculture. According to Wardah Hafidz, feminism questioned the existing norms

${ }^{2}$ Didin Syafruddin, “Argumen Supremasi atas Perempuan: Penafsiran Klasik QS al-Nisā': 34," in Ulumul Qur'an: Jurnal Ilmu dan Kebudayaan. No. 5 dan 6. Vol. V, Th. 1994, 4-10.

${ }^{3}$ Syafruddin. "Argumen Supremasi atas Perempuan..., 7-10. 
and values which tended to discriminate women. ${ }^{4}$ UQ itself documented a dialogue entitled "Perempuan dalam Perbincangan," (Women in Dialogue). A number of scholars and activist such as Wardah Hafidz, Julia I Surya Kusuma, Marwah Daud Ibrahim, Siti Aripurnami, Lies Marcoes, Nursyahbani Katjasungkana, Gevarina, M. Dawam Rahardjo, and Syafi'i Anwar participated in it. In it QS 4: 34 was mentioned and was framed as one of the three trends of woman's issues -Kodrat Perempuan (Woman's Constructed Nature,), Balanced stand or "Yin-Yang stand [it may be defined as a stand that each gender man or woman has equal rights and needs each other, complements each other, neglecting one gender will cause imbalance] ${ }^{5}$ and woman's Power stand [it may be defined as a stand that woman is seen more powerful than man in terms of her strength to catch up with and forbear realities]. Dawam Rahardjo explains that women may not be looked dominant either in public or private sphere, but they actually have certain power to bargain which make them play dominant, such as some of Solo women. They may look not conspicuous in their mobility, but they certainly play dominant role in batik economic affairs. ${ }^{6}$ Kodrat Perempuan basically can be formulated as a stand that woman's status and role are properly following her nature. ${ }^{7}$ As the nature of woman is fluid, her areas of status and role are also dynamic, following her and her community's horizons. Accordingly, woman's status and role are also restricted by her nature, encouraging her to have status and to play role mainly in the areas which are deemed appropriate with her Kodrat. This implies restriction towards women's social participation. However, feminists consider it in its innate dimension formulating it as only God's given nature such as menstruation, pregnancy, delivering a baby, and breast-feeding, all other things are also open to women. They believe that women are basically the same with men in having the same rights to opportunity, role and status. What make a difference are their objective situation, capacity and efforts. In order to open up the horizons which support women's civic engagement this verse has to be interpreted inclusively because this verse is considered as one fundamental basis to formulate woman's status and role in the family as well as in public sphere.

\footnotetext{
${ }^{4}$ Wardah Hafidz. "Feminisme sebagai Counter-Culture," in Ulumul Qur'an, no 5 and 6, Vol. V, 1994, 3.

${ }^{5}$ Balanced stand or "Yin-Yang stand may be defined as a stand that each gender man or woman has equal rights and needs each other, complements each other, neglecting one gender will cause imbalance. Ulumul Qur'an, no 5 and 6, Vol. V, 1994, $43-4$.

${ }^{6}$ Agustina and Ali-Fauzi. Ulumul Qur'an, no 5 and 6, Vol. V, 1994, 50.

${ }^{7}$ Agustina and Ali-Fauzi. Ulumul Qur'an, no 5 and 6, Vol. V, 1994, 48.
} 
Quoting Engineer, some of them including Syafruddin treated QS 4: 34 as the contextual verse which reflected the Arabian social practice at that time. The verse literary says that men are Qawwämün and does not say men have to be Qawwāmīn. And the phrase bimā fad̦ala Allāh ba'dahum 'alà ba'dīn (because Allah has made one of them to excel the other) denotes generality because Allah does not express bimā faḍḍala Allāh ba đ̦ahum 'alāyhinna (because Allah has made some of men to excel women). It means that the Qur'an basically treats man and woman equally, what QS 4: 34 says is only a response to a particular situation. ${ }^{8}$

What Syafruddin and in general Ulumul Qur'an, no 5 and 6, Vol. V, 1994 were intriguing, and they invited further discussions. Since then the verse has been one of source which creates a competing discourse between two opposite stands: literal and contextual group. Recent studies regarding the theme for example may refer to Nina Nurmila's and Masfufah's studies. ${ }^{9}$ Nurmila focuses in her study on the matter of husband-wife relationship in which female leadership is discussed partly where she elaborates QS. 4: 34. She found that the equal interpretation introduced by feminists began to influence the interpretation of the verse since 1990s. It challenges the dominant interpretation which is discriminative towards women. Meanwhile, Masfufah's study has more relevance with the present paper as it discusses female leadership with exclusive reference to QS. 4: 34, mapping two opposite stands of interpretation. However, both fail to take into account adequately the dominant agent in this discourse, the state. This agent's influence is absent from Masfufah's discussion and is inadequate of Nurmila'smone. Other important references are also missing from their discussion, i.e. Al-Qur'an dan Tafsirnya and Tafsir al-Qur'an Tematik: Kedudukan dan Peran Perempuan.

The present paper frames QS al-Nisā' 4: 34 in a broader perspective, and discusses it through the opinions of Indonesian Muslim scholars represented by M. Quraish Shihab's, Hamka's, Husein Muhammad's, and the Ministry of Religious Affairs' interpretation. The study does not include the view of hardliners such as Salafìs interpretation. Their interpretation is also important, but excluded because it has different representation. As the Salafís interpretation

\footnotetext{
${ }^{8}$ Syafruddin. "Argumen Supremasi atas Perempuan...", 8-10; Nurul Aqustina. “Tradisionalisme Islam dan Feminisme," in Ulumul Qur'an, no 5 and 6, Vol. V, 1994, $58-9$.

${ }^{9}$ Nina Nurmila. "Indonesian Muslims’ Discourse of Husband-Wife Relationship," in Al-Jāmi 'ah, Vol. 51, No. 1, 2013 M/1434 H, 61-80; Masfufah. Konsep Kepemimpinan Perempuan Dalam Keluarga: Kajian atas QS. An-Nisā (4): 34. Skripsi. Jakarta: Fakultas Ushuluddin UIN Syarif Hidayatullah, 2013.
} 
represents another extreme pole of thought it deserves special treatment and another adequate discussion. The question of the study is how contemporary Muslim Indonesian scholars interpret QS. 4: 34 in relation to woman's leadership in the context of democracy?

\section{A. Defining Key Terms}

\section{Woman's Leadership}

Leadership literarily means "being a leader," or "ability to be a leader." Its verb "to lead" has these areas of meanings: showing, guiding, influencing, having certain route or existence, and pursuing to be the first or number one. ${ }^{10}$ Actually leadership is a matter of not only agent but also system and practice. In these dimensions, leadership constitutes ability, rights, space and opportunity, processes or practices, learning or enabling process, perception, experience or performance or enacting process. In other words, leadership is always contextualized and situated. ${ }^{11}$ Different contexts and situations construct different meanings of leadership. So, when the term leadership is conjugated with the term female which becomes female leadership or woman which becomes woman's leadership, it tells different stories. How a religion perceives it also reflects another story. For example, the Qur'an contains verses narrating stories about leadership such as the term qawwām (QS. 4: 34), khalifah (QS. 27: 62, QS. 2: 30, QS. 6: 165), imām (QS. 2: 124) and auliyā', (QS. 9: 71) and about woman as well in many of its verses. Even one chapter is deliberately named as al-Nisä', (Women, QS. 4). On one hand, the Qur'an pictures woman and leadership in different information and sometimes they looked contradictory one to another. On the other hand, history tells different practices and responses to the discussed theme reflecting different times and geographies.

A common picture which is in the way of making changes towards more equitable context and situation is that woman's leadership is a matter of marginalized leadership. ${ }^{12}$ Woman's leadership commonly operates within the male world. Two common dimensions characterize it, internally they are struggling with their weaknesses and situation, and externally they are facing challenges from men who have tendency of maintaining their world. ${ }^{13}$ In this

10 AS. Hornby. Oxford Advanced Leaner's Dictionary. Oxford: Oxford University Press, 1989, 708.

${ }^{11}$ Valerie Stead and Carole Elliott. Women's Leadership. Hampshire: Palgrave Macmillan, 2009, 16.

${ }^{12}$ Stead and Elliott. Women's Leadership. 15-9, 130.

${ }^{13}$ Stead and Elliott. Women's Leadership. 58. 
respect, the term Kodrat Perempuan (constructed woman's nature) consciously or not is often used as terms of reference or measurement for both man and woman to perceive woman's social engagement. Within the operative construction of kodrat, female leadership is also operative.

\section{Discourse}

Discourse may be defined as the process of understanding various aspects of and about language which relates to the agent, language usage, and context. ${ }^{14}$ Nasr Hamid Abu Zayd explains it as the search for the relation between the meaning embodied in the Qur'an and meanings in daily life or realities in the form of dialogue, debate, development, acceptance and refusal. ${ }^{15}$ In this study, discourse is understood as concepts or ideas circulated among Indonesian people that are in continuous interactions either in the form of reproduction, modification, or production of social practices. So, discourse of woman's leadership with special reference to QS. 4: 34 is discussed within the larger context of discourse of leadership in Indonesia in general.

\section{Textual and Contextual approach}

Textual approach may be defined as a perspective which treats the wording of the Qur'an, and its literal aspect as the main measurement to uncover meaning, significance and relevance of the message of the Qur'an. This approach considers the primacy of the text of the Qur'an, due to its verbatim divinity. Muslim has only to believe and to follow. Muslim scholars had constructed the characteristics of this approach including the reasons for refusing or restricting woman's leadership. Contextual information is treated only complementary to the primacy of textual consideration. In this approach, woman is not allowed to be a leader, or is allowed but within special circumstances such as in an urgent situation. The approach refers literally to the text of the QS. 4: 34 which says al-rijāl qawwämūna 'alā al-nisā'. The wording of the verse finds another foundation later on among ușüliyyūn's principle, al'ibrah bi 'umūm al-lafzh là bi khusūus al-sabab [indicator or lesson is gained by the universality of word, not by the specificity of cause], ${ }^{16}$ strengthening the

14 John. E. Richardson, (Analysing Newspapers: An Approach from Critical Discourse Analysis. New York: Palgrave Mcmillan, 2007, 22-27.

15 Kusmana, "Heremeneutika Nasr Hamid Abu Zayd: Al-Qur'an sebagai Wacana," in Kanz Philosophia: A Journal for Islamic Philosophy ad Mysticism, Vol. 2 Number 2, 2012, 280.

${ }^{16}$ Hussen Muhammad, Fiqh Perempuan: Refleksi Kiai atas Wacana Agama dan Gender. Yogyakarta: LKiS, 2007, $4^{\text {th }}$ edition, 2001, $1^{\text {st }}$ edition, 202. 
status of husband as leader and accordingly not allowing woman to be one. This interpretation is commonly anchored to the existing social practice which is assumed to be in accordant with Islam. Muslim leaders after the Prophet Muhammad, were almost men. Female Muslim leaders appeared later and very rarely. Referred back to the formative period, Muslims' leadership had been always held by men. Accordingly, in the view of this stand the interpretation of the QS. 4; 34 and also related Hadith is also brought to avoid female leadership. A Hadith of Abu Bakrah reported by Bukhari on the Prophet's stand and prediction of woman leader, Bauran binti Syiruyan ibn Kisra is repeatedly used to support this stand. The prediction was true and this fact is often exploited to abandon female public leadership. ${ }^{17}$ Another Hadith which states that woman's mind is not smarter than man's is also often quoted to discourage woman's leadership engagement. ${ }^{18}$

In contrast, contextual approach may be defined as a perspective which treats context in particular and realities in general as very important resource to uncover the claimed true meaning, significance, and relevance of the message of the Qur'an. It treats the Qur'an either as text or as discourse. The same with the previous approach, this also considers the Qur'an as divine. The difference is that this approach sees contrarily from the previous one in that the contextual approach treats the verse as informative for those who consider the Qur'an as text and as the appropriate solution for the specific time and space for those who treat the Qur'an as discourse. The contextual one considers that in term of the Qur'an as text, man conditionally can be a leader over woman, and woman can be a leader over man as man can be leader over woman. In term of the Qur'an as discourse, man is leader over woman when the context is supportive so, woman is leader over man when the context is supportive so. Textual information is treated as important as contextual information but with a tendency to prioritize the Qur'anic universal vision and mission. In practice this approach can be weighted more on textual consideration as long as the interpretation is in accordant with the Qur'anic vision and mission as the religion of rahmatan lil 'ălamin. The proponents of the group base their argument on the principle of al-Ibrah bi khușus al-sabāb lā bi 'umūm al-lafadz (Indicator or lesson is gained by the speciality of cause, not by the universality of word), and on the principle of maqāsid al-syarī ah, masālih al-mursalah or phronosis (wisdom knowledge/practical knowledge). Among jurists, the two

\footnotetext{
${ }^{17}$ Muhammad, Fiqh Perempuan, 200-1.

${ }^{18}$ Shihab, M. Quraish. Wawasan al-Qur'an: Tafsir Maudhu'i atas Perbagai Persoalan Umat. Bandung: Mizan, 2000 (10 ${ }^{\text {th }}$ Edition $), 313$.
} 
following principles are circulated: al-hukmu yadurru ma'a 'illatihi wujūdan wa adaman (law follows its cause) and là yunkaru taghayyur al-ậkām bi taghayyur al-ahwāl wa azminah [it is no doubt that the change of law is influenced by the change of situations and times]. ${ }^{19}$ And maqāsid al-syarï ah is frequently used to deduce meaning and teachings from Islamic sources. Al-Ghazali defines it as hifzh al-din (maintenance of religion), hifzh al-nafs (respect for life), hifzh al'aql (respect for reason), hifzh nasl (respect for new generation) and hifzh almāl [maintenance of property]. ${ }^{20}$

\section{Democracy in Indonesia}

Democracy basically can be seen as a system which promotes equity, freedom or independence, rationality, justice, and law enforcement. ${ }^{21}$ In putting these values into practice, democracy pays attention to the implementation of rule of law, accountability, responsiveness and open room for a just participation of each citizen regardless ethnics, religions, nation, colour, gender, class or social status. Indonesia always contextualizes democracy into the values which are suitable with Indonesian context, ranging from guided democracy in the Old Order period (1945 -1965), Pancasila-democracy in the New Order era (1966 -1998), to liberal one in Reformasi era (1998 - present). It emphasizes the importance of how the system can guarantee social welfare and justice for (Indonesian) people. ${ }^{22}$ Discussion of woman's leadership is framed within this development of democracy in the country where human rights and gender have evolving since the last third part of The New Order era.

\section{B. The Qur'an and Woman's Leadership}

\section{QS. al-Nisā'/4: 34 and Woman's Leadership}

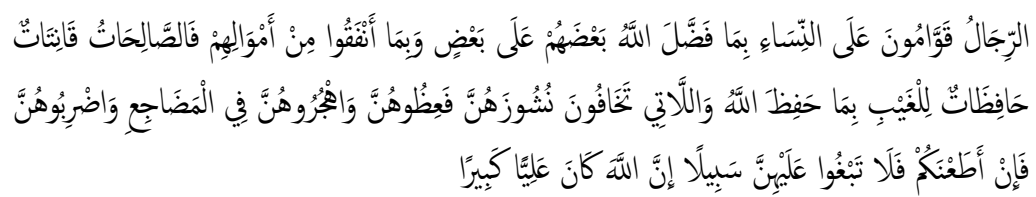

${ }^{19}$ Muhammad, Fiqh Perempuan, 203.

${ }^{20}$ Muhammad, Fiqh Perempuan, 187-8.

${ }^{21}$ Mochtar Pabottingi, "Pengukuran Demokrasi Kita," in Syamsuddin Haris (ed.) Partai \& Parlemen Lokal Era Trnasisi Demokrasi di Indonesia. Jakarta: LIPI, 2007, xxxvii.

${ }^{22}$ Ani Soetjipto, Politik Harapan: Perjalanan Politik Perempuan Indonesia Pasca Reformasi. Tangerang: Marjin Kiri, 2011, 8. 
In this verse, the Qur'an uses the term qawwämūna to refer to leadership. In the same chapter it applies qawwämina (QS. 4: 135) referring to justice perpetrators. The same word is also found in QS. 5: 8, and it means as truth custodians. The word itself according to Baalbaqi can be meant as care taker, custodian, guardian, curator, keeper, supervisor, superintendent. ${ }^{23}$ Louis Malouf translates qawwām as al-mutakaffilu bi al-amri (responsible for something), alqawiyyu 'alā al-qiyām bi al-amri (capable of doing something such as management), or al-amir [leader]. ${ }^{24}$ Muslim interpreters identify the following meanings: pemimpin (leader), pelindung (custodian or guardian), penanggungjawab (responsible for or supervisor), pendidik (educator), and pengatur [manager]. ${ }^{25}$ The official translation and interpretation of the Qur'an published by the Presidency of Islamic Researches, IFTA defines the term as “one who stands firms in another's business, protects his interest, looks after his affairs; or it may be, standing firm in his own business, managing affairs, with a steady purpose." 26 The Qur'an lays down two fundamental dimensions of qawwām: justice and truth. It equalizes justice with truth and vice versa truth with justice. Both values are the basis of interaction and communication. In applying both values certain measurements are adopted to make sure the achievement of the objective, i.e. the objective of marriage, mawaddah wa rahmah (loving and gracious family) and sakinah (harmonious family). The QS. 4: 34 itself discusses leadership in family life where husband is illustrated as the frontier agent in managing family life. The verse mentions literary that al-rijal qawwämūna 'alā al-nisā', exemplifying men or husbands as the persons in charge. And the verse employs the word al-rijala and al-nisā' to represent quality of moral and culture embodied by man and woman. This means culturally constructed. The Qur'an uses al-dhakar and al-Untsa to illustrate man and woman as a sex category, as reflected in QS. Al-An'ām 6: $143 .^{27}$

Munāsabah al-āyāt or relation between this verse with the verse(s) before and after is generally about family life where before QS. 4: 34, the Qur'an [QS.

${ }^{23}$ Rohi Baalbaqi, Al-Maurid: A Modern Arabic English Dictionary. Beirut: Dar El-Ilm Lilmamalayin, 1994, 876.

${ }^{24}$ Louis Malouf, al-Munjid fi al-Lughah wa al-A 'lam. Beirut: Dar el-Mashreq, 1975, 663-4.

${ }^{25}$ Muhammad, Fiqh Perempuan, 196.

${ }^{26}$ IFTA (ed.) $1413 \mathrm{H} / 1992$. The Holy Qur'ān, English Translation of the Meanings and Commentary. Medinna: the Custodian of the Two Holy Mosques King Fahd Complex, 220.

${ }^{27}$ Hanafi, Muchlis Muhammad (Head of Committee), Tafsir al-Qur'an Tematik: Kedudukan dan Peran Perempuan. Jakarta: Kementrian Agama RI, 2012, 14-6. 
4; 33] emphasizes the importance of respect one another, of one's effort, and of avoiding jealousy and suspicion toward the fate of others including in the matters of inheritance, and after [QS. 4: 35] it offers way of solving family problem where the third party or juror can be asked to mediate their problem. The QS. 4: 34 itself describes how a spouse is stated to take leadership in the family when in fact the spouse is the breadwinner of the family and when a problem occurs, the spouse should take a measured step keeping in mind that all approaches taken should be in educational tone. And when the order is restored, the approaches are also advised to be stopped, building one another the harmony of the family.

Though Asbāb al-Nuzūl is not the only source information to discuss the context of a verse, it provides certain information to comprehend its circumstances. According to al-Ṭabarī, the verse was preceded by a question, posted to Muhammad by one of his wives Ummu Salamah regarding the involvement of man in war and inheritance distribution in which a woman receives only half that of man's share. The context of the verse itself informs us of leadership in the family for man due to the burden he holds in the family. ${ }^{28}$

\section{Woman's Leadership in Other Related Terms}

Umar bin Khattab, the Companion and the second caliphate, said that "We in the past did not care about women. When Islam came and God mentioned them, we just knew that they had rights on us". ${ }^{29}$ The Qur'an itself documented this situation saying that "when one of them is told of the birth of a female child, his face is overcast with gloom and he is deeply agitated. He seeks to hide himself from the people because of the ominous [bad] news he has had. Shall he preserve it despite the disgrace involved or bury it in the ground" [QS. Al-Nahl/16:58-61]. ${ }^{30}$ The Qur'an explains that prior to the coming of Islam, the direct context was not supportive for woman' social engagement.

As mentioned above, the Qur'an dedicates one chapter, al-Nisā' for women, known also as al-Nisā', al-Kubrā. It consists of 176 verses of Madaniyyah, informing many aspects of women, from biological, individual to social aspect. Another chapter which informs a lot about woman is al-Thalāq (divorce), known also as al-Nisā' al-Sugrā. It consists of 12 verses of Madaniyyah, informing mainly about rights and obligation of divorce and

${ }^{28}$ Hanafi, Tafsir al-Qur'an Tematik, 14 and 18.

${ }^{29}$ Muhammad, Fiqh Perempuan, 199.

${ }^{30}$ Leila Ahmed, Women and Gender in Islam: Historical Roots of a Modern Debate. New Haven and London: Yale University Press, 1992, 92. 
method to deal with it. The Qur'an also mentions the Queen of Sheba. Here, it actually emphasizes that the Queen of Sheba, Bilqis, was the important leader for her country. ${ }^{31}$ The Qur'an illustrates her to have the following characteristics: democratic, just, dedicative, avoiding violence, not selfish, responsible, and willing to accept truth as reflected in the QS. al-Naml 27: 23$44 .^{32}$ However, this inference did not invite many Muslim interpreters to take this chapter to discuss further about female leadership. Instead they preferred not to encourage it. ${ }^{33}$

In terms of leadership, the Qur'an mentions other terms: khalifah (QS. 27: 62, QS. 2: 30, QS. 6: 165), imām (QS. 2: 124) and auliyā' (QS. 9: 71). The term khalifah is repeated twice in singular form QS. Al-Baqarah 2: 30 and QS. Șād 38: 26, and several times in plural form (khulafá' such as QS. Al-Naml 27: 62, and khaläif such as QS. Al-An ām 6: 165). Literary, khalifah means successor, it refers to leadership due to its function to do isti'mar(development) [QS. Hūd 11: 61] (Shihab. 2000: 424). It is only in QS. Al-An ām 6: 165 the term is used to exemplify the possibility of both man and woman to be leaders. Here, everybody is responsible for what he or she has been doing. The other verses refer to men and in certain case they refer to a single man, such as the Prophet Adam (QS. 2: 30) and the Prophet Daud (QS. 38: 26).

The term imāmah or imām is related with ummah in which both are interconnected through the expectation towards an imām to play roles as source of reference and example for ummah as illustrated in QS. al-Nahl 16: 120. In this verse the Prophet Ibrahim as the exemplary leader to follow. In another verse QS. al-Baqarah 2: 124, Ibrahim was declared to be the leader for human being and his predecessors who were not dallimin were agreed to be leaders too. The term is used in general sense such as in QS. Al-Furqān 25: 74. It informs us of an imām that can also be from anybody, but then Allāh reminds us that a good leader should have certain characteristics to be model leaders. The Qur'an through QS. 25 tells that one has to pray in the night (64), to ask God to set him free from sanction of the Hell (65), to do properly (67), not to worship other than God, to ask redemption and to have strong willingness to accept goodness or correction (70 and 71 ), to refuse false witness, to guard integrity and not to be theft and careless when receive corrections (72-4).

31 Stowasser, Barbara Freyer, Reinterpretasi Gender: Wanita dalam al-Qur'an, Hadits dan Tafsir. Jakarta: Pustaka Hidayah, 2001, 163.

${ }^{32}$ Hanafi, et. al. Tafsir al-Qur'an Tematik, 2012, 8.

${ }^{33}$ Stowasser, Reinterpretasi Gender, 162-5. 
Another term is auliyā' QS. Al-Taubah 9: 71, it means "helpers, supporters, friends, protectors." 34 It notifies that man and woman can be helper including being leader one another in promoting goodness and combating or avoiding wrong doing, and in advocating religious matters. In so doing, a leader is encouraged in the previous verse to learn from the past in which human being contributed to the destruction of nature. A leader who has followed and applied God's messages is introduced in the following verse to receive rewards and big winning. The verse infers promoting or allowing woman's social engagement.

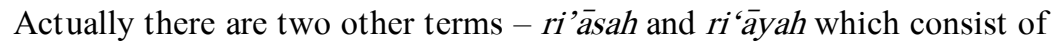
dimensions of leadership, but the Qur'an uses them mostly in its physical meanings, except the QS. Al-Baqarah 2: 279 which says ru'üsu amwālikum meaning "your main property". Other eleven verses refer to physically "head" as part of the body. The Qur'an in Țāha 20: 54 uses the verb "ar'a”" to feed animals with grass. However, the Prophet Muhammad uses the word "rā'in" (from 'ar' $\left.y^{\prime}{ }^{\prime} a u\right)$ to illustrate that everybody is a leader and he or she is responsible for his or her leadership. The Hadith deals with this wisdom was reported by Bukhari and Muslim through 'Abdullah bin Umar. ${ }^{35}$

\section{Indonesian Muslims' Interpretation of Woman's Leadership \\ 1. Indonesian Muslim's Interpretation}

Indonesian Muslim scholars discussed here are restricted into only three figures: Hamka, Muhammad Qurasih Shihab, and Husein Muhammad. All figures accept modernity and democracy with various notes of them. Hamka is par excellent example of Indonesian scholars who have traditional stand towards woman's leadership. M. Quraish is the leading figure who tries to rationalize traditional wisdoms with careful adaptation over new ideas. Meanwhile, Husein Muhammah is an example of a new kind of Indonesian scholar who is affiliated with the traditionalist and has a progressive stand towards woman's leadership discourse.

34 al-Hilāil, Muhammad Taqī-ud-Dīn and Muhammad Muhsin Khān. (Translators), Translation of the Meanings of the Noble Qur'an in the English Language. Madinah: King Fahd Complex for the Printing of the Holy Qur'an, 1417/1996, 256.

${ }^{35}$ M. Quraish Shihab. Perempuan Dari Cinta Sampai Seks, dari Nikah Mut'ah sampai Nikah Sunnah dari Bias Lama sampai Bias Baru. Jakarta: Lentera Hati, 2006 (3 ${ }^{\text {rd }}$ edition), 337. 


\subsection{Hamka}

\section{Interpretation of Qawwām}

Hamka translates part of the QS 4: 34, al-rijāl qawwāmūna 'alā al-nisā', as "Laki-laki adalah pemimpin atas perempuan-perempuan," (Men are leaders of women), and gives a title for the interpretation of this verse "Laki-laki adalah Pemimpin" (Men are Leaders). He claims that this verse is the answer why man deserves to be leader. He illustrates his arguments by pointing out certain man's obligation in the family in this verse, prior to the verse by pointing out inheritance distribution, in other related verses or matters such as polygamy and dowry. Even he literarily says “... wahai laki-laki, wajiblah kamu jadi pemimpin." (hi men, you ought to be leader). Having said so, he forcibly strengthens that men's leadership is reality. Because of this reality, Allah instructs in the QS 4: 34 that man is leader of woman. Accordingly, woman has to obey man's leadership. ${ }^{36}$ So, in his view, if a woman becomes a leader particularly in the family, it is against reality. In his days in 1970s and 1980s when the Tafsir was written this conviction was common. It is why he was sure to say so.

Following the interpretation of al-rijāl qawwāmūna 'alā al-nisā', Hamka interprets ba'dhahum 'alā ba'dhin as "... Allah telah melebihkan sebahagian mereka, yaitu mereka laki-laki atas yang sebahagian, yaitu perempuan.” By identifying ba'dhahum as men and ba'dhin as women, he stresses that men have more in power, and smartness. By characterizing these values, men deserve responsibility, and leadership. Sometimes of course there is weak husband, he uses "tolol" (ignorant) husband and strong wife and he uses "perempuan cerdik" (smart woman) becoming leader of the family. He says we may find so, but the problem is that we cannot make main principle or law base on rarity. Instead it must be based on common practice. ${ }^{37} \mathrm{He}$ asserts that men's leadership over women is not only information, and reality, but it is more importantly God's order. $^{38}$

Hamka also explains another dimension of leadership, i.e. managing a problem. He bases three approaches as introduced in the verse with firmness and wisdom saying "Si suami hendaklah menunjukkan pimpinan yang tegas dan bijaksana" [a husband is expected to be wise and firm leader]. ${ }^{39}$ He frames the three approaches of the verse in the context of actualizing husband's leadership

${ }^{36}$ Hamka, TafsirAl- Azhar, Juz'u V, Jakarta: PT. Pustaka Panjimas, 1999, 1984 $1^{\text {st }}$ ed., 45-6; Hamka, Tafsir Al-Azhar, 1999, $19841^{\text {st }}$ ed., Juz'u V: 45-6.

${ }^{37}$ Hamka, Tafsir Al-Azhar, Juzu' V., 46-7.

${ }^{38}$ Hamka, Tafsir Al-Azhar, Juzu' V, 47.

${ }^{39}$ Hamka, Tafsir Al-Azhar, Juzu' V, 49. 
in the family when his wife did a nusyüz (ill conduct) with kind advice, or separation in bed or in extreme situation with dharb (slapping). He underlines that $d$ harb is only permitted in a way which is not harming the wife and not in the face because the purpose of it is only a way to make her aware of her mistake and willing to obey his leader. Obedience is another dimension of leadership. Hamka asserts that it is important to make leadership effective by implementing obedience. The wife is expected to obey her husband to give opportunity his leadership is operative effectively, but with a note, as long as the husband runs the leadership of the family on the tract. ${ }^{40}$ If a problem occurs persistently, and levels off on shiqa $q$ as mentioned in the following verse QS. 4: 35 (Hamka translates it as "retak menghadang pecah"/near to breaking down), a husband as leader is expected not to push himself to overcome the problem, because he is part of the problem. In this situation, the third party is invited to solve their problem. Here, Hamka interprets the following verse as part of the husband's leadership in which he puts it as the limit of leadership when the husband himself arrives at his limit. ${ }^{41} \mathrm{He}$ concludes his interpretation by quoting part of the speech of Wada' of Muhammad in which woman was part of his great concern to pay attention to, quoting Ittaqu Allāha fí al-Nisā', fainnahum 'awānun 'indakum [Fear to Allah pertaining Women, they certainly lifetime friend of yours]. ${ }^{42}$

\section{Its Related Terms}

Hamka begins his interpretation of the term khatifah with its generic meanings, "pengganti" (successor). He then identifies its usages in the Qur'an, finding three different forms (lafzu al-mushtāq): khalifah, khulafā, and khaläif. Khalifah is used twice QS. Al-Baqarah 2: 30 explaining about Allah's will to create one on the Earth, and QS. Șä 38: 26 illustrating the Prophet David (Daud) as one on the Earth. Khulafa is the plural form, used in QS. Al-A raf 7: 69, and 74, and al-Naml 27: 62. Khaläif is used in QS. Al-An ām 6: 165, Yunus 10: 14 and 73, Fathir 35: 39 illustrating that successor will come from generation to generation. In interpreting the term with its various forms, Hamka does not determine the sex except for the form khalifah, QS. al-Baqarah 2: 30 as Adam, and QS. Șād 38: 26 as Daud. ${ }^{43}$ It may be because he keeps his consistency to assert that leadership belongs to man.

\footnotetext{
${ }^{40}$ Hamka, Tafsir Al-Azhar, Juzu' V, 48-53.

${ }^{41}$ Hamka, Tafsir Al-Azhar, Juzu' V, 53-9.

${ }^{42}$ Hamka, Tafsir Al-Azhar, Juzu' V, 53.

${ }^{43}$ Hamka, Tafsir Al-Azhar, Juz'u XX, 7.
} 
Hamka returns to the term auliyā' to its singular form and selects "pimpinan" or "pemimpin" (leader) as its meaning. He contextualizes this meaning in QS. Al-Taubah 9: 71 in the relation of mu'min versus munāfiq. Following the wording of the verse, leadership here can be applied between man and woman. He writes "Mereka bersatu, pimpin meminpin, yang setengah atas yang setengah, bantu membantu, laki-laki dengan perempuan" [They are united, lead one another, part over another part, help each other, man with woman]. ${ }^{44}$ However, he does not deliberately say that woman can be leader of man. Instead, he repeatedly explains that woman can play important role in every area of life as man does including in the war situation. That role for sure should be in accordant with woman's nature. He gives example by mentioning women's participation in Uhud war by providing water, and helping the wounded. $^{45}$

Seeing from the interpretation of imām in QS. al-Baqarah 2: 124, Hamka explains leadership in terms of religious leadership (Imamat Agama). Ibrahim's leadership is religious leader. Ibrahim is par excellent example of how leadership trajectory should be constructed, i.e. through heavy examination. According to Hamka, Ibrahim's examination to be leader is testing the limit of patience, trustworthy, and obedience. However, he infers this case a lesson learned in that he claims that "Imamat yang sejati haruslah melalui ujian" [true leadership should be resumed through examination]. ${ }^{46}$ In all other terms discussed above, Hamka does not deliberately mention that woman can be a leader. It is because he believes that that leadership belongs to man.

\subsection{Muhammad Quraish Shihab \\ Interpretation of Qawwām}

Muhammad Quraish Shihab does not translate the term qawwām of QS.

4: 34 in his Tafsir al-Mishbāh and his book Perempuan, left as it is. He interprets it as "pemimpin and penanggungjawab" (leader and care-taker). ${ }^{47}$ However, he does translate it directly as "pemimpin dan penanggungjawab" (leader and care-taker) in Al-Qur'an dan Maknanya [the Qur'an and its Meanings] (Shihab. 2010b: 84), and only "pemimpin" (leader) in Wawasan alQur'an [The Qur'anic Perspective]. ${ }^{48}$ The reason behind these differences may

\footnotetext{
${ }^{44}$ Hamka, Tafsir Al-Azhar, Juz'u X, 275.

${ }^{45}$ Hamka, Tafsir Al-Azhar, Juz'u I, 275-6.

${ }^{46}$ Hamka, Tafsir Al-Azhar, Juz'u I, 294-5.

47 Shihab, Tafsir al-Mishbāh: Pesan, Kesan dan Keserasian al-Qur'an, Vol. 2. Jakarta: Lentera Hati, 2000, 402; Shihab, Perempuan, 333.

${ }^{48}$ Shihab, Wawasan Al-Quran, 310.
} 
return to the development of his thought or style of writing. As admitted by Shihab himself, his understanding of the term developed from 1996 when his Wawasan was published and later publications -al-Mishbāb 2000b, Perempuan 2005, and al-Qur'an dan Maknanya 2010. In Wawasan, his opinion was the same with the majority of Muslim interpreters' that man is leader of woman in the family. Since the publication of Tafsir al-Mishbāh, he rationalizes his interpretation of the verse, inspired by Muhammad Thahir ibn Asyur. Ibn Asyur asserts that the term al-rijāl is not used in Arabic language and the Qur'an to denote husband, but it refers to man in general. Meanwhile, the term al-nisä' or imra'ah is used to characterize wife. It means that the verse informs about man and woman in general, and this functions as introduction for another part of the verse, i.e. the attitude of pious wives (Shihab. 2000b. Vol. 2: 404). Shihab interprets al-rijāl qawwämūna 'alā al-nisā', as men are leaders of and care-taker of women. Basically Shihab's interpretation of the verse looks the same with many other interpreters including Hamka in terms of treating the Qur'an as Text. Similar with majority of interpreters, he interprets the verse as it is in the Qur'an. However, he has made changes by reinterpreting keys terms such alrijāl and al-nisā'. He tries to make sense of the message of the Qur'an to modern audients.

With regards to the style of writing, the way Shihab presents his thoughts either in speech as reflected in his speeches in seminars or religious dakwah, or in his writings as the man who put audients' acceptance as the most priority. As his context is modern age, Shāfi ' $\bar{i}$ 's school adherents which are moderate, and the moderate attitude of Indonesian people in general, Shihab always tries to win the majority, and he did it elegantly as many of his books are always best seller and his speeches are waited to listen to. Keeping these points in mind, we witness his great effort to comprehend QS. 4: 34 as clear as possible, and as reasonable as possible to modern audients. He uses different discourse resources to say that men deserve leadership and women ought to obey men as long as the matter is within Islamic teachings, ranging from the wisdom of the nature of the body, philosophy, psychology, to, of course, religious studies. The following different figures are consulted: Muhammad Thahir ibn Asyur, Anton Nemiliov (Russion scholar), Murtadha Muthahari, Abu al-Zahra al-Najafi (translator of Muthahari's Nizām Huqūq al-Mar'ah), Reek, Cleo Dalon, Mauriche Bardeche, Thabari, Ghazali, Fakhruddin al-Rāzi, ibn 'Arabi, and Atha. ${ }^{49}$ This conclusion is the same with what the text itself literarily infers. What make Shihab's interpretation is different from many

49 Shihab, Tafsir al-Mishbāh, Vol. 2, 402-12. 
others in terms of leadership is that this verse does not direct him to hindrance woman's leadership by explaining that the term qawwām consists of fundamental values of leadership such as fulfilling needs, paying attention, maintenance, defence, and guidance. ${ }^{50}$ In another page, he also mentions obedience which is part of the verse, but here, obedience is treated as part of leadership as the Qur'an includes it to leadership. The context of the verse places obedience of woman to illustrate an effective leadership. Man and woman can have these values through learning process and self-capacitybuilding. Shihab does not go outside the box in his interpretation. He only follows the wording of the Qur'an in that he is also the same with many other interpreters in that he puts woman to implement obedience and man to actualize order in order to maintain harmony in the family.

\section{Its Related Terms}

Shihab indentifies two meanings of khalifah which derives from khalf. "menggantikan" (to replace) and "yang datang sesudah siapa yang datang sebelumnya" [who comes after the one who comes earlier]. ${ }^{51}$ The first meaning constitutes a successor who represents a predecessor such as a prince who replaces a king. Meanwhile, the second meaning constitutes a successor can be from different descendants, different generations, and different places. Shihab concludes that the plural form khulafa refers to political power within an area, such as reflected in QS. al-Naml 27: 62 which illustrates levels of taking advantages, ownership, the inheritance of the Earth from generation to generation (Shihab. 2002. Vol. 10: 255), and the plural form khalaif refers to everybody from generation to generation without entailing the concept of political power as in the first meaning, such as in QS. Al-An ām 6: 165 which informs that due to the trust given by God towards everybody to be leader, and everybody has different capacity, skill, and knowledge, everybody man and woman is eligible to leadership depending on objective qualifications, competition and networks. All these create differences which make different levels one from another (Shihab. 2003, 20011 ${ }^{\text {st }}$ ed. Vol. 4: 365; Shihab. 2010: 150). Here, by quoting al-Sya'rawi who translates khalifah as Allah's gift of a little part of His power, he translates it as human who acts as God's representative in the Earth in which each human is able to do things with God's

${ }^{50}$ Shihab, Tafsir al-Mishbāh, Vol. 2, 404.

${ }^{51}$ Shihab, Perempuan; Shihab, Tafsir al-Mishbāh, 2000. $1^{\text {st }}$ ed., 142; Shihab, Tafsir al-Mishbāh, Vol. 4, 362. 
consent. $^{52}$ Shihab translates imām as "pimpinan atau teladan" (leader or exemplary), and it is not given to those who transgress others. From this meaning, it can be inferred that leadership and "ketauladanan" are not inherited by descendants, blood relationship, and kinship. Leadership is resumed through examination as experienced by the Prophet Ibrahim. In short, Shihab concludes that leadership will be given by God through faith and piety, knowledge, and examinations, as well as avoiding dhulumāt or harming others. ${ }^{53}$

Shihab interprets auliyä' as "penolong-penolong" (helpers), and the term denotes believers. ${ }^{54}$ The believers characterize as helpers one another, man over women or vice versa woman over man in everything (good). Though not stating as his opinions, Shihab quotes again Thahir ibn 'Âsyur and here Sayyid Qutb too. Ibn 'A Asyur characterizes the term as having values of sincerity in helping one another. Qutb stresses the points of braveness, helping one another, providing fund, and responsibility. ${ }^{55}$ In Wawasan (1996), Shihab interprets the verse in the context of political participation. He explains that this verse describes collaboration between man and woman for various subjects of life, encouraging them to do ma'ruf (goodness) and avoid "mungkar" (wrong doing). He includes collaboration, assistance, and occupation or power to the meanings of auliyā. 56

\subsection{Husein Muhammad}

\section{Interpretation of Qawwām}

Husein Muhammah approaches the Qur'an from a sociological and contextual point of view, as he calls it. ${ }^{57}$ Though he does not define what he means with it, he understands the Qur'an as the information which documented the existing social practices. The Qur'anic teachings consist of universal message and cases which responded the reality. He characterizes the Qur'an as having universal purposes of kemaslahatan (public utility), kerahmatan (mercifulness), keadilan (justice) and kebijaksanaan [wisdom]. ${ }^{58}$ In other words, verses which contain cases are treated as examples of the ways the Qur'an approaches realities. In the case of the QS. 4: 34, he considers it as an example

${ }^{52}$ Shihab, Tafsir Misbah. Vol. 4: 363-5.

${ }^{53}$ Shihab, Tafsir Al-Misbah. Vol. 1, 317-8.

${ }^{54}$ Shihab, Tafsir Al-Misbah. Vol. 5, 650; Shihab, Al-Qur'an dan Maknanya. Jakarta: Lentera Hati, 2010, 198.

${ }^{55}$ Shihab, Tafsir Al-Misbah. Vol. 5, 650-51.

${ }^{56}$ Shihab, Wawasan Al-Quran, 315; Shihab, Perempuan.

${ }^{57}$ Muhammad, Fiqh Perempuan, 198.

${ }^{58}$ Muhammad, Fiqh Perempuan, 186-7. 
of a discourse documented by God. It is at the time of revelation leadership was commonly resumed by man. Leadership comes with responsibility and obligation in the side of leader, and it comes with obedience in the side of follower as long as the leader performs his tasks on the right track. It is actually basic value of leadership today too. He identifies Muslim interpreters' search for the meaning of the term qawwām as leader, protector, care-taker, educator and manager. He himself uses two meanings of it: care-taker, and leader. In Fiqh Perempuan, he translates it as either care-taker or as leader. He actually translates part of the verse al-rijāl qawwämūna 'alā al-nisā' as 'Laki-laki adalah qawwām atas perempuan..." [Men are qawwām over women]. ${ }^{59}$ Here, he does not interpret it, he just discusses how interpreters interpret the term differently. Having explained so, he begins to discuss his opinion in that he invites readers to see other aspects of it, i.e. sociological and contextual aspects. He asserts that subordinate status of women was reflected from patriarchal society. It is reasonable if the Qur'an does not delete or replace all discriminative social practices. The Qur'an too does not adopt previous social practice totally, but approaches them wisely, strategically, and pragmatically to keep its fundamental messages compatible with the existing demands: kemaslahatan (public utility), kerahmatan (mercifulness), keadilan (justice) and kebijaksanaan [wisdom]. ${ }^{60}$

However, in Islam Agama Ramah Perempuan, he translates qawwām as "Penanggungjawab keluarga atau qawwām atas kaum perempuan" [care-taker of the family or qawwām over women]. ${ }^{61}$ This interpretation is still consistent with his opinion in Fiqh Perempuan in that he tries to be careful in interpreting it. He actually continues in constructing his thought further in this book. He explains that while the Qur'an was presented initially to the people of Middle East, it witnessed the superiority of men over women. However, the Qur'an did not easily and directly admit and accept this discriminative culture. The Qur'an only accepted the social practices which were not against humanistic principles. Accordingly, he asserts that the Qur'an proposes criticism, revision, and new ideas which are compatible with humanity, equity and justice. He further illustrates:

“Al-Qur'an juga mengakomodasi realitas sosial tentang lemahnya potensi intelektualitas perempuan dalam urusan-urusan ekonomi, yang oleh karena itu, kesaksiannya dalam urusan tersebut memerlukan dua

\footnotetext{
59 Muhammad, Fiqh Perempuan, 196.

60 Muhammad, Fiqh Perempuan, 198-9.

61 Muhammad, Islam Agama Ramah Perempuan, 61.
} 
orang agar memiliki kekuatan sebanding seorang laki-laki. [QS. AlBaqarah: 282] Kelemahan perempuan juga terjadi karena memang diposisikan lemah oleh masyarakatnya. Tradisi Arab waktu itu memperlakukan perempuan seperti layaknya tawanan. Nabi Saw., melihat kenyataan ini dan melakukan advokasi terhadap mereka. Nabi Saw., selalu menyampaikan pesan al-Qur'an Wa'āshirūhunna bi alma'rüf (dan bergaullah dengan mereka [kaum perempuan] menurut cara yang ma'rüf) [QS. Al-Nisā' 19]. Cara-cara yang ma' ruf adalah cara-cara yang baik sesuai dengan budayanya. Pada kesempatan yang lain Nabi juga menyampaikan pesan al-Qur'an Mereka adalah pakaian kamu dan kamu adalah pakaian mereka [QS. Al-Baqarah 197]. Ini juga mengandung makna kesetaraan suami dan istri. Dalam banyak kesempatan, Nabi selalu berpesan agar kaum perempuan harus diperlakukan dengan baik. Sebaik-baik orang di antara kalian adalah yang terbaik memperlakukan istrinya, kata Nabi."

The Qur'an accommodates social realities of the weak female intellectual potency in economic affairs too, it is therefore, their witness in this matter requires two persons in order to have the strength of one male witness [QS. Al-Baqarah 282]. Women's weakness is also justified from the fact that they were positioned so by the society. Arabic traditions at that time treated women as if they were prisoners. The Prophet, Peace be upon him, saw this reality and advocated women. The Prophet always addressed the Qur'anic message, Wa'āshirūhunna bi alma'rüf (and treat them [women] with ma'rüf) QS. Al-Nisā' 19. Ma'rūf methods are good methods which are in accordant with the culture. In another occasion, the Prophet also addressed the Qur'anic message of They are your cloths as you are their cloths [QS. Al-Baqarah 197]. This message contains also the meaning of equity between husband and wife. In many occasions, he always gave advice to treat women well. The best persons among you are those who treat their wives well, the Prophet said]. ${ }^{62}$

All information used by Muhammad is also often used by others who discriminate women, but the way he uses them is totally the opposite. If others use them to emphasize the limited space and opportunity that women have. On the other hand, Muhammad used them to emphasize a quite different discourse,

${ }^{62}$ Muhammad, Islam Agama Ramah Perempuan, 62-3. 
the discourse of the Qur'anic democracy or equity as reflected in QS. AlHujurāt 49: 13. It treats human being the same regardless their gender. ${ }^{63}$

In another place in Islam Agama Ramah Perempuan, he translates the term qawwām as leader but he mentions it in bracket. ${ }^{64}$ The context of using this meaning is the interpreters' use of the meaning in their works. Muhammad himself uses it not to support man's leadership over woman. The verse is informative and not normative. ${ }^{65}$ However, the verse also infers the possibility of woman's leadership over man depending on the objective situation. In his view, the following part of the verse, bimā faddala Allāhu ba'dahum 'alā ba'din, denotes relativity in leadership, depending on objective conditions and situation. He asserts that no absolute point in superiority of one over another. Man and woman are eligible to be leader as long as they deserve to be so or capable of being so. God only underlines certainty in superiority in the matters of piety where Allah guarantees their nobility in front of Him. ${ }^{66}$

Unlike others, he relates the story of the Queen Bilqis of Sheba Kingdom, as a point that supports the equity of gender in the Qur'an. Historically, he also mentions female sufi, Rabi ${ }^{\text {ah }}$ al-Adawiyah as a case of woman's superiority over man. He believes that history and the message of the Qur'an meet at the spirit of Islam as the religion of just, universal, and rahmatan li al-'ālaminn [Godsend for the universe]. ${ }^{67}$

\section{Its Related Terms}

Besides quoting QS 49: 13, Muhammad also refers to other verses to illustrate equity between man and woman in doing goodness and to encourage collaboration between them: QS. Al-Nahl 16: 97, al-Ahzab 33: 35, al-Taubah 9: 71. Furthermore, he identifies that the current situation is changing towards more democratic and equal social practices. This shift implies a change in context. Accordingly, new context needs new laws to support new practices. Previous values which place women second class are needed to be evaluated and seek for new answer. New answer in his view is the interpretation of religious sources in the spirit of equality, human rights and democracy. Included to the change of situation is that many women are upgraded in education, skill,

63 Muhammad, Islam Agama Ramah Perempuan, 64-5.

${ }^{64}$ Muhammad, Islam Agama Ramah Perempuan, 81.

${ }^{65}$ Muhammad, Islam Agama Ramah Perempuan, 91.

${ }_{66}$ Muhammad, Islam Agama Ramah Perempuan, 92.

${ }^{67}$ Muhammad, Islam Agama Ramah Perempuan, 91-3. 
knowledge and network. All of these developments contribute to the change of the context. Now, many women are as eligible as men to uphold leadership. ${ }^{68}$

\section{State's Discourse of Woman's Leadership}

\subsection{The Qur'an, Translation and Interpretation}

According to Al-Qur'an dan Terjemahnya published by the Department of Religious Affairs, al-rijāl qawwāmūna 'alā al-nisā', was translated as "Kaum laki-laki itu adalah pemimpin bagi kaum wanita" [Men are leaders of women].

"Kaum laki-laki itu adalah pemimpin bagi kaum wanita, oleh karena Allah telah melebihkan sebahagian mereka (laki-laki) atas sebahagian yang lain [wanita], dan karena mereka (laki-laki telah) menafkahkan sebagian dari harta mereka. Sebab itu maka wanita yang saleh ialah yang taat kepada Allah lagi memelihara diri ketika suaminya tidak ada, oleh karena Allah telah memelihara (mereka). Wanita-wanita yang kamu khawatirkan nusyuznya [meninggalkan kewajiban bersuami istri], maka nasihatilah mereka dan pisahkanlah mereka di tempat tidur mereka dan pukullah mereka. Kemudian jika mereka mentaatimu, maka janganlah kamu mencari-cari jalan untuk menyusahkannya. Sesungguhnya Allah maha Tinggi lagi Maha Besar." [QS. 4: 34]

Men are leaders over women, because Allah has made one of them to excel the other [woman]. And because they [men] spend from their means. Therefore, the righteous women are devoutly obedient to Allah and guard themselves when their husbands are absent, because Allah has guarded them. As to those women whose part you see their nusyuz [leaving husband-wife's obligations], admonish them and refuse to share their bed, and beat them. But if they return to obedience, seek not ways to make them in difficult situation. Surely Allah is ever Most High and Most Great. ${ }^{69}$

This version of translation has additional explanation which could be included as part of interpretation. In this verse, the phrase of al-rijal qawwämūna 'alā al-nisā' had not additional explanation though. The version was published initially in 1971 and regularly reprinted following the demand. The translation and interpretation of this version was done by a commission headed by Prof. R.A.H. Soenarjo, S.H. The translation which is used in this

68 Muhammad, Islam Agama Ramah Perempuan, 65-70.

69 R.H.A. Soenarjo, Head of Committee. 1989, 19711st ed. Al Qur'an dan Terjemahnya. Jakarta: Depaertemen Agama, 123. 
quotation is 1989 version which was coordinated under the ministry of Munawir Sjadzali. What does it mean in terms of the development of meaning of the term qawwām? It means that from the first publication up to Munawir's time 19711989 [18 years] or 1990 [19 years], the state still considered that man was leader of woman. As we know Munawir was one of progressive Muslim thinkers who had contributed to the development of Islamic thought in Indonesia, particularly that of political thought and law of inheritance. But, in the case of gender, he seemed maintain the mainstreamed discursive resource. Actually, the state had ratified CEDAW (Convention on the Elimination of All Forms of discrimination Against Women) in 1984, five years after the UN passed it in 1979. However, the government did not follow it up with a real binding regulation, institution and implementation. The state started to pay serious attention to human rights after it established the Indonesian Commission of Human Rights, well known as Komnas HAM in 1993, in which it was headed initially by Munawir Sjadzali himself. And even, five years later the state established another national commission, but for women, called Komnas Perempuan (The National Commission on Violence Against Women, or Komnas Perempuan) in 1998.

However, in 1990s new meanings were introduced to this stand. The translation and interpretation of the Qur'an, entitled the Holy Qur'an: English Translation of the Meanings and Commentary published by the Custodian of the Two Holy Mosques King Fahd Complex (1413/1993) translated al-rijäl qawwāmūna 'alā al-nisā' as "men are protectors and maintainers of women." The meaning as protector is introduced in the previous verse, mawāi in which one of its meanings is protector, i.e. heirs who protect the property left by parent. However, the editors select protector as the meaning of qawwäm to illustrate characteristics of good husband in appreciating good wife. She "is obedient and harmonious in her husband's presence, and in his absent guards his refutation and property, and her own virtue."70 By doing this, women's leadership is left not discussed. It can be inferred though, that leadership is a matter of natural law in that it depends on objective qualification and competition. The King Fahd Complex for The Printing of the Holy Qur'an also printed the same document entitled the Noble Qur'an: English Translation of

${ }^{70}$ IFTA. 1413 H/1992. The Holy Qur'ān, English Translation of the Meanings and Commentary, 219. 
the Meanings and Commentary in 1417/1996 and translated part of the verse as "Men are protectors and maintainers of women."

The Indonesian state started to consider the change of meanings of the term qawwām ten years later in 2004 when Ministry of Religious Affairs published Al-Qur'an dan Tafsirnya. This works was initially written by a team headed by Prof. R.H.A. Soenarjo, S.H., in 1972, revised by another committee headed by Prof. H. Bustani A. Gani 1973, and seven years later in 1980 it was revised again by another committee headed by Prof. K.H. Ibrahim Husein, LML. The present version is a new revision, began in 2004 done by a committee headed by Dr. Akhsin Sakho Muhammad. The committee translates the term only as "pelindung" (protector), in which the Holy Qur'an and the Noble Qur'an above mention it the same meanings. However, Al-Qur'an dan Tafsirnya entitles the interpretation of the verse as Peraturan Hidup Suami Istri" (Regulation of Husband -Wife Life) and interprets the verse in this respect. Though the team translates the term qawwäm as male protector which is one of the meanings of the term, they include it in their interpretation, because the husband has to manage and be responsible for his family. It is therefore the first sentence of the interpretation of the verse is "Kaum laki-laki adalah pemimpin, pemelihara, dan pemberi nafkah, bertanggungjawab penuh terhadap kaum perempuan yang menjadi istri dan menjadi keluarganya." (Men are leaders, maintainers, defenders, and breadwinners of women who are responsible fully towards women which are their wives and part of their families) These exclusive rights are ineffective when husbands do not fulfil their obligations, and certain mechanisms are provided to solve a tension. ${ }^{72}$

\subsection{Women's Leadership in the State's Tasir al-Qur'an Tematik}

Another state's important source in discussing women's leadership is Tafsir al-Qur'an Tematik. This book was initially started in 2008 done by a team headed by Dr. Muchlis Muhammad Hanafi, M.A.. The present edition which was published in 2012 is the revised version. This book is one among five other books. All the books were intended to provide information about Islam to Indonesian Muslims. It was expected that these publications give new response towards changing situations. These books are structured similar with the themes of the state's Rencana Pembangunan Jangka Menengah Nasional/RPJM

71 al-Hilāli and Muhsin Khān, translators. 1417/1996. Translation of the Meanings of the Noble Qur'an, 113.

${ }_{72}$ Sakho, Head of the Committee. Al-Qur'an dan Tafsirnya Vol. II. Jakarta: Kementrian Agama, 2004, 153-4. 
(National Strategic Medium Development Plan): economic development, stat us and role of woman, ethics in family, society and politics, conservation, and health issue. ${ }^{73}$ The book calls women not to forget their main tasks, i.e. to provide better generation. The term qawwäm is translated as "pelindung" (protector), but then places the verse in sub-chapter "Kepemimpinan Perempuan dalam Keluarga" [Female Leadership in the Family]. ${ }^{74}$ Its function as pelindung is to membimbing (guide), mengayomi (protect), and mencari nafkah (being bread winner). However, before quoting this verse, the committee mentions a Hadith narrated by Muslim from Ibn 'Umar which explains that everybody is leader of him himself or of her herself and on what he or she is responsible for, to illustrate the neutrality of gender in leadership. In it, it explains that man [husband] is leader of the family and woman [wife] is leader of the family and their children. Both are responsible for their leadership. Though referring to this Hadith to state that leadership is open for both man and woman, the committee plots leadership as Amanah (trust) in earlier pages and states that leadership is a heavy duty, and it is most appropriately given to man. Woman may become leader but in certain areas. In the family, a wife becomes a co-leader with her husband, and in publics woman may become leader, but in the area such as in education which she can maintain her main task of proving better generation and guarding the family. ${ }^{75}$ In other words, through this book, the state maintains female leadership discourse which is anchored to the properness of Kodrat Perempuan (woman's constructed nature).

\section{Woman's Leadership Discourse in Modern Indonesia}

The QS al-Nisā'/4: 34 has always been used to discuss woman's status and role including the matter of woman's leadership since its formative history of Muslim. The nature of leadership in the verse and its related verses as discussed above is fluid embodying the universal aspect of Islam which is rahmah li al-'älaminn, equal and public utility or maslahah, and at the same time reflective response of the objective situation in the revelation time. In its relation to lafaz mushtāq, lafaz mutarädif, and Hadith the QS 4: 34 and woman's leadership contain meanings and dimensions of leadership where the term qawwām embodies the dimensions of responsibility, protection, justice and truth. Whereas the other terms consist of also protection, eligibility of man and woman to be leaders, isti'mar or development, help one another, and

\footnotetext{
${ }^{73}$ Hanafi, Head of Committee, "Pendahuluan", 2012, xiv-xvii.

${ }^{74}$ Hanafi, Head of Committee, "Pendahuluan", 54.

${ }^{75}$ Hanafi, Head of Committee, "Pendahuluan", 47-73.
} 
responsibility. The Qur'an seems infer specificity where it mentions special figure such as the Prophet Adam and Ibrahim, and denote generality in which any man and woman is eligible to resume power when the needed requirements are fufilled. It is interesting to note that the Hadith quoted in this paper reflects reciprocity of leadership between leader and follower, and responsibility of being leader regardless gender. This section provides either normative or informative aspects of the message of the Qur'an. To deduce it depends on approach (es) he or she deploys in which it basically implies to either textual or contextual in character.

However, in practice, interpreters are not always successful in differentiating them due to various reasons. Writing is an effective media for maintaining things including interests, and ideologies, after all. This complexity becomes problems of interpretation. Woman's leadership in Indonesia is not free from this situation. It has always been described as constrained under female Kodrat (female constructed nature). Woman's status and role are deeply influenced by their nature. This influence ever grew greater since the coming of external influence from the West and Middle which supported practices of woman's status and role as supporting agent with main task at home and educator of children, known simply as traditional roles. This value is pervasive covering various areas of life including education and citizenship where woman is formulated as citizen which supports the success of her male citizen. For some of Indonesian Muslim interpreters, this discriminative practice is seen as supporting data to infer meaning from the Qur'an. It is obvious when Hamka for example deduces that the proper leader is man due to inferences from the Qur'an, Sunna, history, and local practices in Indonesia.

It seems that the interpretation which was dominant in classical period retains in Indonesian context up to present time. The interpretation that man is leader over woman is still firmly held by modernist as reflected in Hamka's interpretation of the verse. He even entitles the interpretation of QS 4: 34 as "Laki-laki adalah Pemimpin," [Man is leader]. ${ }^{76}$ He actually infers the possibility of woman to be leader by referring to other related terms such as khalifah, imām and auliyā, but his basic stand tends to prioritize man as leader over woman. He neglects the possibility of woman's leadership over man, due to its rarity. He exemplifies that sometimes we are in a situation of having "laki-laki tolol" (unintelligent man) and "perempuan cerdik" (smart woman) as unintended situation and it is rare case. Norm is always based on generality and not on rarity (Hamka. 1983. Juz'u V: 47).

\footnotetext{
${ }^{76}$ Hamka, Tafsir Al-Azhar Juz'u V, 1983, 46.
} 
The state also participated in maintaining this kind of interpretation as reflected in al-Qur'an dan Terjemahnya, al-Qur'an dan Tafsirnya, and Tafsir alQur'an Tematik: Kedudukan dan Peran Perempuan. It gives the impression that this kind of interpretation is calculated to appeal to Indonesian Muslim audients whose perspectives to Islam can be traced back to the mediaeval period. So, man is leader over woman by nature, norm, and sociological fact. Woman may only be a leader when the situation necessitates so, and in the areas deemed appropriate with their Kodrat. In this point, the state introduces what it calls as a co-leadership in the family. Wife is a co-leader of the family with main task of maintaining better generation. This inference is deduced from a Hadith narrated by Muslim from Ibn 'Umar as explained in sub-chapter above. This meaning is new translation of the traditional role of woman in the family in which in essence it is still the same with the traditional wisdom. In modern time this meaning has been rationalized. This implies a change though insignificant. Accordingly, woman is allowed to be leader not only in the urgent situation, but also in other areas of engagement, as long as their Kodrat is maintained and they are needed so. For example, in the introduction of Tafsir al-Qur'an Tematik the head of the team elucidates the meaning of gender and its implication for understanding the religious teachings which is clear and aware when it is applied. However, in term of woman's leadership, the possibility of woman to be leader in any kind of position, even the president of a state is expressed in conditional sentence. He worded this possibility by saying "Kepermimpinan perempuan terkait dengan atau bagian dari kepemimpinan keluarga, kepemimpinan dalam ibadah juga dapat menjadi imam bagi sesamanya dan anak-anaknya. Perempuan juga dapat tampil dalam masyarakat sebagai pemimpin jika keterampilan memimpinnya dibutuhkan, bahkan sebagai pimpinan Negara," family, leadership in worship too in which a woman can be leader over her female mates and their children. Woman can also engage in social activity as a leader if her leadership is needed, even as head of a state]. The phrase "...jika keterampilan kempemimpinnya dibutuhkan...," (... if her leadership skill is needed,...) can be clearly understood that the book prefers man's leadership to woman's one.

However, more changes also happen in the meaning of leadership, as new rationalization and meanings are inserted in more recent time. For example, more moderate attitude arises. M Quraish Shihab, a case in point, interpolates objective conditions to both man and woman to resume power with

\footnotetext{
${ }^{77}$ Hanafi, Head of Committee, "Pendahuluan," 8.
} 
appreciation of man's leadership over woman in the family with careful and thoughtful argumentation. Findings of scientific inquiries as well as new thoughts of subjective speculation of philosophy are deployed to make sense the old wisdom of the verse. He also reinterprets key terms such as qawwām as leader and care-taker, al-rijāl as man in general and al-nisā' as having characteristics of wife which implies different meanings, more equal particularly for woman. He also shows other related terms such khalifah, imām and auliyā which place man and woman as eligible agents to be leaders. For that reason, the interpretation of the QS 4: 34 manages to have more changes. In his view, man is leader over woman in the family conditionally. It means that woman is also possible to resume one. However, he does not go further for example to say woman can be leader over man as man can be leader over woman. Instead he only rationalizes the traditional wisdom.

Further interpretation of QS 4: 34 has been made, and more changes are found. New interpretations of QS 4: 34 which was introduced by modernists such as Muhammad Abduh and his student Rasyid Ridha, and many others including M. Q Shihab are also further introduced, extending the treatment of the Qur'an as text to the Qur'an as discourse. Husein Muhammad though does not use a discourse analysis in his elucidation of the verse he makes some elaborations treating the verse as a discourse. The way he applies it is by mixing the analysis the Qur'an as text and as discourse. As text, he is the same with Shihab in treating the phrase al-rijāl qawwämūna 'alā al-nisā' and bimā faddala Allāh ba'dahum 'alā ba'din, in that he interprets consecutively men are care-takers and leaders over women and because Allah has made one of them to excel the other. The difference is that Shihab rests in prioritizing man over woman, whereas Muhammad treats them as optional depending on objective conditions. Shihab goes further only on the point of the possibility of woman to be leader in as many fields as men have with that note of preference. In contrast, Muhammad goes further by treating also the verse as discourse, putting it as a case. So, the verse is informative and not normative. He is sure that the present context is better context for actualizing the ideal vision of the Qur'an which is democratic, just, wise, public, and rahmah li al-'ālamīn. Accordingly, democratic and equal interpretation of the Qur'an is more preferable.

Having discussed the diachronic aspect of QS 4: 34, the synchronic aspect reflects another dimension. That is novelty of the idea of new interpretation. More than two decades ago Syafruddin invited readers to reinterpret the verse. What have been discussed so far, efforts have been made 
either by the state which was absent in his study or Muslim scholars, including in Nurmila's and Masfufah's study. Two contexts are interesting to look at to: the context when Syafruddin wrote the paper and the context where I write my study. With regard to the first context, Syafruddin who studied at IAIN Jakarta majoring in Arabic language for his undergraduate and studied Qur'anic study at the Institute of Islamic Studies McGill University for his M.A., with the thesis on Ibn Taymiyyah's principles of Interpretation, and had read references on women and feminism as reflected in his quotation, had accurately documented the stage of discourse of the verse in the context of feminism discourse. The stage was in an urgent need to reinterpret the verse. Actually at that time, a number of publications on feminism appeared though many were not written by Muslim Indonesians. This absent was fulfilled by the present other Muslim writers whose works were imported to Indonesia and some were translated. In this case, UQ was one important media that helped introduce the new discourse in Indonesia. For examples, Amina Wadud Muhsin, Wanita di dalam al-Qur'an (1994), Fatima Mernissi, Wanita di dalam Islam (1994), Mazhar ul-Haq Khan, Wanita Islam Korban Patologi Sosial (1994), and Asghar Ali Engineer, Hak-hak Perempuan dalam Islam (1994), were introduced and reviewed. As reflected in UQ, No. 5 and 6 Volume V 1994, Indonesian readers have been introduced to the idea that QS 4: 34 is informative and not normative. This point is resulted from reinterpretation of the wording of the verse. External considerations were also interpolated to support that woman can be leader as man does. Since then publications on feminism and gender issues increased rapidly, as reported by for example, Dinamika Studi Gender IAIN Sunan Kalijaga 1995-2003(2004). Soon after that, Indonesian Muslim scholars felt invited to share their thought. One of the early works may refer to Yunahar Ilyas who wrote the thesis on feminism in the Qur'anic perspective in 1996 (Ilyas.1996). In his study, he referred to Aminah wadud and Asghar Ali Engineer. Another Muslim feminist was also referred, Riffat Hassan. Regarding the discussion of QS 4: 34, he made no change, if his is compared to Syafruddin's. He stopped his analysis only on causes of differences of thought between classical and modern scholars. Zaitunah Subhan, another example participated also in responding the invitation. She approached the verse literarily, making analysis on the term al-rijāl by picking another meaning of it as walking and moving. In contrast, al-nisä' is feminine, domestic, and even forgetting. Both meanings of the two terms are characteristics, man and woman 
can have those characteristics. Biologically, al-rijäl are men, but sociologically they can be men or women depending on the characteristics they have. ${ }^{78}$

What is interesting is the role of the state in this discourse. The state has not changed in its policy of the kind of Islam that it should really protect and develop. The state maintains classical wisdom and makes some efforts to rationalize its interpretation as reflected in the discussed works. The voice of the state is similar with one voice of Indonesian Muslims who also have the similar stand. They are majority, and guarding their discourses. In other words, the mainstreamed voice is supported by the state, it makes man's superiority over woman stable.

Meanwhile the other context, i.e. the time of this study is carried out. It seems that it informs a similar picture with the previous context, but with different accentuations and nuances. This is so because its proponents of the competing agents receive and gain new supporters with a dominant characteristic of the state's discursive interpretation. On one hand, the textualist stand receives its supporters from mass organizations both local and international decedents and Muslim scholars which maintain the interpretation of Salafi thought and the state's new interpretation over the verse. These groups' interpretation is believed to have a threat to restrict woman's social engagement. On the other hand, the contextualist stand collects the support of reformist and liberal scholars as well as mass organizations which support equal interpretation of the verse. The problem is that though the state has shifted its political paradigm into a more democratic political system since Reformsi era, and new or updated supportive gender equity institutions and regulations are also strengthening the spirit of democracy and gender equity, discriminative nuance of leadership concept retains its foot and even finds a new soil which is nurtured by both state's and scholars' interpretation as reflected in their interpretation over the QS. 4: 34. However, the other agent, the supporter of just interpretation of the verse, paves the way of nurturing its land due to its situation of having backed up with the shifting paradigm of the state, just regulation and institutions. In short, the contemporary context provides new evident, methodologies, institutions as well as thoughts in which both opposite stands use them in the negotiation over the interpretation of the verse which reaches a new level of competition.

${ }^{78}$ Zaitunah Subhan, Rekonstruksi Pemahaman jender dalam Islam. Ciputat; ElKahfi, 2002, 176-7. 


\section{Conclusion}

The discourse of woman's leadership seeing from the case of interpretation QS. 4: 34 in modern context of Indonesia informs an enduring negotiation between continuity and change in meanings of the religious text. The negotiation rests mainly in two models of interpretation: textualist and contextualist. Each has its own agents that support their arguments. Woman's leadership in the history of Islam evolved from being neglected prior to the coming of Islam, liberated in the period of the Prophet Muhammad, negotiated in the following periods but with tendency to restrict them, and confiscated since Medieval period, to being treated as competing discourses between restrictive and liberalizing discourse since second half of the $20^{\text {th }}$ century. Referring to QS 4: 34 the discourse of female leadership in Indonesian context had found an adequate rivalry since 1990s in which new approach, method and thought were introduced to challenge the dominant discursive meanings, i.e. man superior over woman. The wisdom which nurtures patriarchal values retains even gains new engine supplied by Muslim scholars such as Hamka and Shihab, mass organizations, and the state's interpretation of the verse as well. Though still minority, the proponents of the contextualist interpretation as done by Husein Muhammd appear greater and stronger as equal and just role and opportunity of gender are irresistibly inviting different discursive sources of female leadership.

\section{Reference}

Agustina, Nurul and Ali-Fauzi, Nasrullah. "Perempuan dalam Perbincangan,: in Ulumul Qur'an: Jurnal Ilmu dan Kebudayaan. No. 5 dan 6. Vol. V: 42-51, 1994.

Ahmed, Leila. Wanita dan Gender dalam Islam: Akar-akar Historis Perdebatan Modern. Jakarta: Lentera, 2000.

-------. Women and Gender in Islam: Historical Roots of a Modern Debate.

New Haven and London: Yale University Press, 1992.

Andaya, Barbara Watson. The Flaming Womb: Repositioning Women in Early Modern Southeast Asia. Honolulu: University of Hawai i Press, 2006.

Aqustina, Nurul. “Tradisionalisme Islam dan Feminisme," in Ulumul Qur'an, no 5 and 6, Vol. V: 52-63, 1994.

Baalbaqi, Rohi. Al-Maurid: A Modern Arabic English Dictionary. Beirut: Dar El-Ilm Lilmamalayin, 1994. 
Hafidz, Wardah. "Feminisme sebagai Counter-Culture," in Ulumul Qur'an, no 5 and 6, Vol. V: 3, 1994.

Hamka, Tafsir Al-Azhar, Juz'u I, V, X, XX. Jakarta: PT. Pustaka Panjimas, 1999, 1 edition 1984.

Hanafi, Muchlis Muhammad (et.al). "Pendahuluan" in Kedudukan dan Peran Perempuan. Jakarta: Kementrian Agama RI, 2012.

al-HilāTi, Muhammad Taqī-ud-Dīn and Muhammad Muhsin Khān (Translators). Translation of the Meanings of the Noble Qur'an in the English Language. Madinah: King Fahd Complex for the Printing of the Holy Qur'an, 1417/1996.

--------. Edited by Fazal Ilahi Zahir (et.al.). the Noble Qur'an: English Translation of the Meanings and Commentary. Medinah: King Fahd Complex for the Printing of the Holy Qur'an, 1417/1996.

Hanafi, Muchlis Muhammad (Head of Committee), Tafsir al-Qur'an Tematik:

Kedudukan dan Peran Perempuan. Jakarta: Kementrian Agama RI, 2012.

Hornby, AS., Oxford Advanced Leaner's Dictionary. Oxford: Oxford University Press, 1989.

IFTA (ed.) The Holy Qur'ān, English Translation of the Meanings and Commentary. Medinna: the Custodian of the Two Holy Mosques King Fahd Complex, 1413 H/1992.

Ilyas, Yunahar, Isu-isu Feminisme dalam Tinjauan Tafsir al-Qur'an: Studi Kritis terhadap Pemikiran Mufassir dan femnis Muslim. Thesis, Yogyakarta: Pascasarjana, 1996.

Kumar, Ann, Prajurit Perempuan Jawa: Kesaksian Ihwal istana dan Politik Jawa Akhir Abad e-18. Jakarta: Komunitas Bambu. 2008.

Kusmana, "Heremeneutika Nasr Hamid Abu Zayd: Al-Qur' an sebagai Wacana," in Kanz Philosophia: A Journal for Islamic Philosophy ad Mysticism, Vol. 2 Number 2, 2012.

Malouf, Louis, al-Munjid fï al-Lughah wa al-A 'lam. Beirut: Dar el-Mashreq, 1975.

Masfufah, Konsep Kepemimpinan Perempuan Dalam Keluarga: Kajian atas QS. An-Nisā (4): 34. Skripsi, Jakarta: Fakultas Ushuluddin UIN Syarif Hidayatullah, 2013.

Muhammad, Husein, Islam Agama Ramah Perempuan : Pembelaan Kiai Pesantren. Yogyakarta: LKiS, 2004.

. Fiqh Perempuan: Refleksi Kiai atas Wacana Agama dan Gender. Yogyakarta: LKiS, $20074^{\text {th }}$ edition, $20011^{\text {st }}$ edition. 
Muhammad, Dr. Ahsin Sakho (Head of the Committee), (2004).Vol. I, (2004). II, (2007). III, (2007). IV, (2007).VII, (2007).VIII. Al-Qur'an dan Tafsirnya. Jakarta: Kementrian Agama.

Nurmila, Nina, “Indonesian Muslims' Discourse of Husband-Wife Relationship," in Al-Jämi 'ah, Vol. 51, No. 1, 2013 M/1434 H, 61-80.

Pabottingi, Mochtar. "Pengukuran Demokrasi Kita," in Syamsuddin Haris

(ed.) Partai \& Parlemen Lokal Era Trnasisi Demokrasi di Indonesia. Jakarta: LIPI, 2007.

Al-Qur'ān al-Karīm wa tarjamatu ma ānihi ilā al-lughah al-Indūnīsiyyah. Medinah: Mujamma' Khadim al-Haramain as-Syarifain al-Malik Fahd, li thiba' at al-Mushhaf asy-Syarif.

Richardson, John. E., Analysing Newspapers: An Approach from Critical Discourse Analysis. New York: Palgrave Mcmillan, 2007.

Ridwan, Zaenab. Al-Nadhariah al-Ijtimāi iyyah fì al-Fikri al-Islāmī: Ushūluha wa bināuha min al-Qur'ān wa Sunnah. Kairo: Dār al-Maēarif, 1982.

Shihab, M. Quraish, (2000a 10 ${ }^{\text {th }}$ Edition). Wawasan al-Qur'an: Tafsir Maudhu' $i$ atas Perbagai Persoalan Umat. Bandung: Mizan.

, (2006 $3^{\text {rd }}$ edition). Perempuan Dari Cinta Sampai Seks, dari Nikah Mut'ah sampai Nikah Sunnah dari Bias Lama sampai Bias Baru. Jakarta: Lentera Hati.

, (2000 10 ${ }^{\text {th }}$ Edition). Wawasan Al-Quran: Tafsir Maudhu'i atas Pelbagai Persolan Umat. Bandung: Mizan.

-------, Tafsir al-Mishbāh: Pesan, Kesan dan Keserasian al-Qur'an, (2000b).Vol. 2, (2006).Vol I, (2001, 2003).Vol 4, (2002).Vol 10, (2002, 2004).Vol 5. Jakarta: Lentera Hati.

-------, 2010. Al-Qur'an dan Maknanya. Jakarta: Lentera Hati.

Stowasser, Barbara Freyer, Reinterpretasi Gender: Wanita dalam al-Qur'an, Hadits dan Tafsir. Jakarta: Pustaka Hidayah. 2001.

Stead, Valerie and Elliott, Carole. Women's Leadership. Hampshire: Palgrave Macmillan, 2009.

Subhan, Zaitunah, Rekonstruksi Pemahaman jender dalam Islam. Ciputat; ElKahfi. 2002.

Syafruddin, Didin, “Argumen Supremasi atas Perempuan: Penafsiran Klasik QS al-Nisā': 34," in Ulumul Qur'an: Jurnal Ilmu dan Kebudayaan. No. 5 dan 6. Vol. V: 4-10, 1994.

Wieringa, Saskia Eleonora, Penghancuran Gerakan Perempuan di Indonesia. Jakarta: Garda Budaya. 1999. 
Wiraatmadja, Rochiati, Dewi Sartika. Jakarta: Depdikbud, Direktorat Sejarah dan Nilai Tradisonal, Proyek Inventarisasi dan Dokumentasi Sejarah Nasional, 1983 2ed., 1980 1st ed.

Soenarjo S.H., Prof. R.H.A. (Ketua Tim), Al Qur'an dan Terjemahnya. 1989, First edition 1971. 